Indiana University Purdue University - Indianapolis

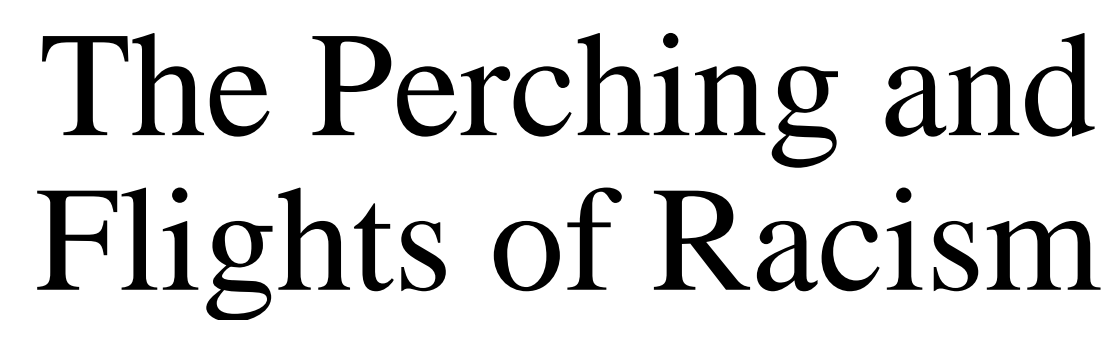

Continuing to Gain Knowledge of the Perceptions of Young Adult Black Men and Political Activation

\author{
Troy Crayton \\ Fall 2019 \\ 8917 Squire Ct. \\ Indianapolis, IN 46250
}

ORC ID: \#0000-0001-5936-0850 


\title{
The Perching and Flights of Racism:
}

\section{Gaining Knowledge of the Perceptions of Young Adult Black Men and Political Activation}

\begin{abstract}
Racism is not some static conception reflecting merely xenophobic feelings or hierarchical mindsets among individuals (Miles and Brown 2003). The term "racism," in association with questions of democracy and individual opportunity, has risen into the primary weltanschauung of the American political and social psyches as represented by the September 12, 2019 Democratic Debate, political organizations, and political media. Given this weltanschauung, the purpose of this article is to seek additional knowledge toward coming to understand the perceptions of young adult Black men's perceptions and political activations when prompted by the phenomenon of racism. Interpretative phenomenological analysis was engaged in the study of the YABMs to gain their reflective meaning-making and to protect against researcher biases. Key findings established that references to matters political involved the participants experiences with their communities, concerns with helping others in that community in a reciprocal manner, and the exclusionary practices found that challenges said community. These characteristics occur simultaneously as a meaning" of "the political" for each of the participants (Miller 1980). Theoretically, the extent to which these characteristics played into their perceptions of the political in-turn affect their decision-making and activations of political perceptions and behaviors. This theoretical conception was carried forward toward gaining knowledge of young adult Black men's perceptions of political experiences serve as a source of data for this article; specifically, the data referencing matters of race (Crayton 2019).
\end{abstract}

Keywords: racism; race; ideology; politics; political; power 


\section{INTRODUCTION}

The term "racism," in association with questions of democracy and individual opportunity, has risen into the primary weltanschauung, or perceived ways of the world, of the American political and social psyches as represented by the September 12, 2019 Democratic Debate, political organizations, and political media. Given this weltanschauung, the basis for this reflection is born in association with how the perceptions and political activations of young adult Black men may be affected. Said another way, when presented with the term "racism," how does engagement with that term affect how social constructs influence young adult Black men's' perceptions and subsequent engagement with the "political" (Miller 1980)? As Miller (1980:56) conveys,

The meaning of "political" is not just a problem for semantics. It is a question that political scientists must confront at the outset of inquiry, for inquiry in any science "can properly begin only after one has specified in some way, vaguely and naively, as it may be, the kind of thing he intends to investigate.

Miller (1980) explains a consideration of a distinction to keep in-mind as one analyzes how one individual comes to understand and perceive a political subject or political activity differently from the next perception. In a recent study conducted by Crayton (2019), young adult Black men were found to process meaning and perceptions of 'the political' commonly and fluidly among their respective meaning-making and decision-making processes when presented with subject matter reflective of politics. The process contributes to his perceptions given prior lived experiences with: 1) the capacity and motivation to help others reciprocally; 2) said 'help' is drawn most closely through an association with others of similar cultural experiences, referred to as their 'community'; and 3) whereas there is a shared social experience among 'the 
community' that has presented exclusionary practices for which some level of resistance is revealed (Lukes 2005; Ryan and Deci 2017). For the purposes of this article, racism shall be the default exclusionary practice being considered unless otherwise suggested.

Miles and Brown (2003) and Kendi (2019) advise that arguments related to race must first be solid among discussants on term meanings, including intended nature of the specific term. Ryan and Deci (2017), speaking to bases for individual motivations and perceptions advise that "pervasive cultural norms or economic structures present 'invisible' or implicit values, constraints, and affordances, (are) then reflected in more proximal social conditions and conveyed by socializing agents" (Ryan and Deci 2017:562). Thought of from a perspective of satisfaction of basic psychological needs, they are advising that values, constraints, and concordances toward acting are associated with encounters with social conditions including engagement with social structures, and socializing agents of institutions affects the incorporation of the young adult Black man's (YABM) values, constraints, and concordances, however (Omi and Winant 2015; Ryan and Deci 2017). But what if the specific pervasive or its' proximal social conditions are represented merely when a YABM associates either of these encounters as prompted by the term 'racism' through language or another social construct?

The balance of the article consist of the following subsections: What is Racism; Racism is an ideology; The racism weltanschauung as coherent and incoherent phenomena; Methods; Findings; Discussion; and Conclusion. The What is Racism? subsection will present a basis for what racism is and what it is not in relation to the purpose of the article. The content establishes a position from which the article has engaged the relationship between the term racism, its conceptual nature, and the developing perceptions of the YABMs. The next subsection, Racism is an ideology, initiates the heart of the argument for how the YABM of the study has 
represented a process through which he comes to make meaning and decisions, including what prompts his perceptions.

The racism weltanschauung as coherent and incoherent phenomena presents an explanation for the relationships among 'the ways of the world' related to racism. Specifically, a presentation of the significance for how the prejudices and exclusionary practices of the weltanschauung affect the perceptual processes of the participant YABM. And to bring to conclusion, the article will incorporate the typical sections including the methods, findings, discussion, expressed as a conversation among various authors, and the conclusion as an approach toward offering a theory for gaining knowledge for how the participants engage their respective meaning and decision-making processes.

\section{What is Racism?}

Racism is not some static conception reflecting merely xenophobic feelings or hierarchical mindsets among individuals (Hirschfeld 1938/2016; Miles and Brown 2003). Miles and Brown (2003) provide a basis from which to establish a basis for its nature and mutual understanding for folks. Such a basis must be established to later discuss perceptions of the YABMs respective ideological perspectives about exclusionary practices and policies related to 'race' and the engagement of the YABM. The extent to which the exclusionary practice or policy inhibits his decision to act in his best interests is associated with his "[individually based] specific representational characteristics that must exist to warrant description as racism" (Miles and Brown, 2003:103) toward coming to perceive social constructs and processes.

Ryan and Deci (2017) advise that such analyses should incorporate the YABM's reflected upon and disclosed basic psychological needs including his feelings that he is able to act autonomously, with feelings of competence, and relevant to what he is attempting to 
accomplish to counter exclusionary practices and policies (Ryan and Deci 2017). The participating YABMs, when referring to 'the political', did not use the term 'racism' when associating reflected responses to questions about that which is understood as political in nature (Miles and Brown 2003; Miller 1980). However, implications of the conception for engaging a 'certain context of thinking' were prevalent throughout the YABMs' respective reflective responses when reflections involving race were engaged.

A study participant, Acey, introduced the notion of perceiving preconceived notions about him as an exclusionary practice related to race (Crayton 2019; Heitzeg 2015). The other participants conveyed similar preconceived notions thought the contexts of their reflections either directly or indirectly. The contexts were typically related to feelings of being perceived criminals merely based from exclusionary practices and policies that are xenophobic or phenotypic observations of other folks (Awokoya 2012; Heitzeg 2015; Hibbing, Smith, and Alford 2014). Miles and Brown (2003) emphatically argue that the nature of 'racism' is not static and limited to these bases. Hirschfeld (1938/2016) explain that these were bases for the initiating uses of the modern use of the term 'race', however. Although the term racism was not used explicitly in association with what was conveyed as the influence of these preconceived notions due to the YABMs perceived race, these associations reveal that these characteristics must be considered in more detail in any analysis of individual perceptions (Miles and Brown 2003).

Miles and Brown (2003) would quickly continue to argue that the xenophobic and phenotypically associated beliefs about 'race' related terms must be distinguished, especially the term 'racism'. They first explain that the nature of 'racism' must account for the meaningmaking and decision-making processes including the YABMs' respective: 1) individual 
ideology; 2) individual interpretations of "“less coherent assembly of stereotypes, images, attributions, and explanations that are constructed and employed to negotiate everyday life', and that 3) 'racism refracts in thought certain observed regularities, and constructs a casual interpretation that can be presented as consistent with those regularities and that constitutes a solution to perceived problems"” (Miles and Brown 2003:104-105). Ryan and Deci (2017) and Omi and Winant (2015) include that the understanding of the term 'racism' must concord with the need to include the YABMs' respective identity, cultural experiences, and levels of resistance to the hegemony of the weltenschauung.

\section{Racism is an Ideology}

An “ism," for Merriam-Webster (2019), represents "forming nouns denoting a system, principle, or ideological movement" (https://www.merriam-webster.com/dictionary/ism).

William James, $19^{\text {th }}$ century psychiatrist and philosopher in an essay The Streams of Consciousness, is credited with recording the musings that thought and consciousness are akin to a bird coming to rest on a limb and taking flight noninterrupted. That said, the foundation begins to establish that the term 'racism' is ideological in-nature and plays a part in developing and representing the principles and perceptions of the meaning and decision-making processes for YABM. Specifically, as he is confronted with exclusionary practices related to race. Heywood (2003) explains various versions and evolutions for the meaning of the term, ideology. For the purposes of this article, ideology is through the Gramscian sense represent both a political and economic perspective through which to interpret wat the YABMs may be reflecting (Heywood 2003; Miles and Brown 2003; Miller 1980). The nature of the Gramscian ideology as expressed by Heywood (2003:7) explain that

the capitalist class system is upheld not simply by unequal economic and political 
power, but by what he termed the 'hegemony' of bourgeois ideas and theories. Hegemony means leadership or domination, and in the sense of ideological hegemony it refers to the capacity of bourgeois ideas to displace rival views and become, in effect, the commonsense of the age.... This bourgeois hegemony, Gramsci insisted, could only be challenged at the political and intellectual level, which means through the establishment of a rival 'proletarian hegemony', based on socialist principles, values and theories.

Heywood (2003) exemplifies the portion of the weltanschauung (hegemony) that relates to the economic relationship to the meaning-making and decision-making processes as potentially exclusionary for the YABMs and thus associated with his ideological system. A system of ever developing principles, beliefs, values, attitudes, and cultural influences and the meaning and decision-making processes by which the YABM react to the world - an ideology of racism (Duckitt and Sibley 2010; Hibbing, Smith, and Alford 2014; Miles and Brown 2003). Ball, Dagger, and O'Neill (2014) and Duckitt and Sibley (2010) exemplify the significance of affects upon individual attitudes, etc. and their ideological systemization especially through political thought. To be clear, Heywood (2003) conveys that an 'ideology of racism' (IOR) applies to all as an oppressed person and as an oppressor - everyone has an IOR.

DiAngelo (2018:1-2) actually specifies a difference in how white folks attitudes allow them to engage in matters of race. She argues that it is not "really possible to grow up in the United States or spend any significant time here - or any other culture with a history of Western colonization - without developing opinions on racism. And white people's opinions on racism tend to be strong." Of course, folks may be different, but generally, it is taken away that there would be a perceived tension from the beginning among white and Black folks engaging in 
matters of 'race'. Hirschfeld (1938/2016:257) attribute such tensions to folks having a "natural self-preservative impulse (that is) sometimes described as an inferiority complex and sometimes as the sense of guilt - for they are closely akin."

These conflicting self-preserving feelings related to matters of race are "continuous, yet fluid phenomenon" (Miles and Brown 2003:6) and therefore simultaneously a part of folks IOR - the individual's system of processing principles, perceiving, meaning-making, and decisionmaking. Moreover, Miles and Brown (2003) argue that racism is a social construct that is adopted as a causal characteristic of the weltanschauung, albeit based on false understandings and the Walker (2019) version of DuBois' (1897) double consciousness.

Walker's (2019) version is an elaborated form of DuBois' original conception in that it includes the dynamic phenomena of power as a critical proportion to that exclusionary feeling that double consciousness imbues upon the YABM as a characteristic of the weltanschauung. Miles and Brown (2003:9) represent this weltanschauung when stating that its' basis represents human beings and social relations, in a distorted manner while never denying that, qua ideology, racism can be simultaneously deeply embedded in the contemporary Weltanschauung and the focus of the struggle on the part of those who challenge its hegemony.

In other words, for the YABM, the ideology or belief processes built through historical, cultural, political, representational and economic experiences for perceiving and reacting to the current social conditions consist of exclusionary phenomena that produce forces of resistance for him. Brave and Sylva (2007) and Scott (1992) exemplify the literature in conveying that forms of resistance are common when interacting with hegemonic conditions that present some form of conflict for an individual. Lukes (2005) advises, moreover, that hegemonic social conditions consist of varying levels of power that oppose societal resistance, either individual or as a 
collective. Walker (2019) argues for an extension of an understanding of the effects of double consciousness as a social influence that appears as power over individual YABMs. They represent their distinction from DuBois' double consciousness through an introduction of elements of power. As Walker (2019:122) states,

For an identity group, $\mathrm{X}$, to claim double consciousness, they must be an oppressed group with an oppressor, Y. If Y does not have power (be that political, social, or economical) over X, X cannot claim double consciousness. This is because Y's prejudice and power gives them the capability to cause tangible consequences for X. So, whites (as Y) would not have a claim to double consciousness even though a definition of whiteness would exist.

Walkers' (2019) elaboration of DuBois' conception of double consciousness would require evidence that some tangible consequence results from a decision made by the YABM. Lukes (2005) elaborates on such characteristics of one's IOR in terms of power. Carmichael (2018) would cosign in that at a point in his musings he exclaimed that "racism is not a question of attitude; it's a question of power" (Carmichael 2018:1) and engaging one's IOR. For Lukes (2005), a consideration of power is revealed through a form of domination over folks in terms of affecting folks' IOR in evidence of institutional power.

Ideologically, the YABMs of the study exhibited characteristics of Walker's (2019) double consciousness as an influencer of their IORs and political activations. These ideological thinking processes reflected another characteristic of the YABMs perceptions labeled racialisation (Miles and Brown 2003). This conception of racialisation is identified as part of the causal thinking processes by which the YABMs categorize the understanding of racial related social constructs has him thinking in terms of associating himself with being "other" as a 
part of his identity (Artiles 2011; Eberhardt 2019; Miles and Brown 2003). When experiences include exclusionary practices associated with being 'othered' by some agent or product of the weltanschauung, it accentuates the thought processes, including the initiating perception of the phenomena.

The matter of 'othering' complicates the double consciousness characteristic of engaging the YABMs' respective IOR. Hirschfeld (1938/2016) explains that an individual's feeling of nationalism, or, belonging to a 'nation' like the Cherokee or Blackfoot nations of native Americans may become a factor that engages the IOR. It is this equivocation to an individual feeling a sense of belonging to a group of folks who share "historical, cultural, political and other distinguishing factors of a 'nation' are ultimately subsumed under the idea of 'race'” (Miles and Brown 2003:10) and the associations assigned to the term. The historical, cultural, and political associations of the YABMs serving as bases for certain perceptions and satisfaction of basic psychological needs (Ryan and Deci 2017).

The historical, cultural, and political associations include 'race' as an idiom adopted by the YABM to exemplify resistance or inner conflict produced through the double consciousness (Brave and Sylva 2007; Scott 1992). The resistance presents throughout the reflective responses of the YABM study participants as a result of a sense of belonging to a 'nation' that is presumed to be 'other than' a dominant 'nation' exacerbated through conditions such as whiteness as presented in the weltanschauung of American society as reflected upon by the YABMs of the study (Duncan and McCoy 2007; Heitzeg 2015; Lukes 2005). Coming to mind, then, is the concurrent emergence of white nationalism in the same weltanschauung. The coemergence of the concerns with racism and exhibitions of white nationalism becomes another point-forconsideration perhaps for another study. 
Miles and Brown (2003) further explain that this racialisation weltanschauung "presupposes a process of racialisation but is differentiated from that process by its explicitly negative evaluative component" (p.104). Artiles (2011) links such categorizations of difference to the educational system by which the YABMs are 'conditioned through the negative aspects of 'othering', for example. The process then reveals additional characteristics of individual thinking that exposes constructs that destabilizes his causal bases for acting to satisfy his own basic psychological needs for those that are dictated through the conditioning of pervasive and proximal (i.e. exclusionary practices and policies) social constructs (Walker 2019).

The three dimensions process includes the presentation of the social influence into the a YABMs' IOR in the first place; evidence for an agenda that sets up a causal decision; and ultimately altering one's decision as a 'tangible consequence' of a conditioned understanding of the social constructs (Lukes 2005; Walker 2019). Whereas 'tangible consequences' are represented by the YABMs' respective identities and behavioral processes that effect his respective IOR and his world experience (Miles and Brown 2003; Ryan and Deci 2017). Specifically, when the economic, political and culturally representational aspects of his IOR are affected by exclusionary practices of racism. Those consequences could be due to both founded and non-founded in nature, but influential upon a YABM nonetheless (Miles and Brown 2003).

\section{The racism weltanschauung as coherent and incoherent phenomena.}

The IOR holds both coherent and incoherent characteristics that provide knowledge for the participants' negotiating life (Miles and Brown 2003). Whereas the coherent portion of the nature of his IOR is based from the causal relationships, and, the incoherent portion for a YABM consists of the prejudices and exclusionary social practices based from the "assembly of stereotypes, images, attributions, and explanations that are constructed and employed to negotiate everyday life" (Miles and Brown, 2003:104). As further consideration of social 
practices go, then, so also the consideration of institutions closely follows (Hodgson 2006).

Institutions are dynamically intertwined entities within a societal weltanschauung (Hodgson 2006; Searle 1995). Hodgson (2006:2) establish that "institutions are the kinds of structures that matter most in the social realm: they make up the stuff of social life (and defined) as systems of established and prevalent social rules that structure social interactions.". And it is habit that acts as a mechanism by which institutions, its agents, rules and practices realize influence over individuals (Hodgson 2006). For example, when an individual conveys that there has been a racist act, that equates to some exclusionary practice, such as reference to some somatic or some attributed characteristic (positive or negative in intent) to a group, because of its basis in some physical association in identifying the 'other', as products of the institution of racism. A commonality of experiencing an exclusionary practice becomes habituated (i.e. acquisition of habit) and therefore maintaining the institution because of 'automated' reactions to said racist practice. Contributing further to their explanation for the nature of racism as institution, Miles and Brown (2003:112) include that "racism is embodied in exclusionary practices or in a formally non-racialised discourse" while also signifying "exclusionary practices that result in disadvantage for racialised groups cannot be assumed to be determined wholly or in part by racism."

A final characteristic of coming to understand the IOR as an ideology of individuals and its coherency is that it allows for an assignment of, perception of, and reaction to experienced regularities that have seemed to be acceptable resolution to perceived problems of a YABM (Miles and Brown 2003). They elaborate upon what they are arguing through including regularities as a descriptor for causal behavior, by associating the nature of the mechanism consisting of the class assignment of the individual. In other words, social class also plays into 
the processes as well. As presented a short time ago, speaking to social class (i.e. economic, political, and representational/cultural) indicates that there is tangible consequence at-play for YABMs whereas there are recognized regularities and potentially habituated problem-solving exercise that he employs.

Contributing to the approach and interpretations of the YABMs' respective perceptions of a given encounter with racism and the associated habituated response. Although there may be a habituated response, elements of resistance are ever potentially presented in the processes like those prompted by feelings of Walker's (2019) double consciousness, that would also play into his perceptions and response. As Miles and Brown (2003:171) suggest, those potential resistant responses would involve a historically comparable experience; his specific "class interests and strategies, different strategies (learned) of resistance, and different material and cultural contexts." Each simultaneously contributing to the meaning making, decision-making, perceptions of, and responses - the respective IORs - to social constructs like those presented by racism.

\section{METHODS}

Prior to getting to the heart of the approach to methods, a brief description for each sampled YABM participant engaged for this article are offered. The data utilized for this article was borrowed from a recent study that Crayton (2019) conducted with a group of YABMs, aged 18-22. That study, Toward Gaining Knowledge of Young Adult Black Males' Perceptions of

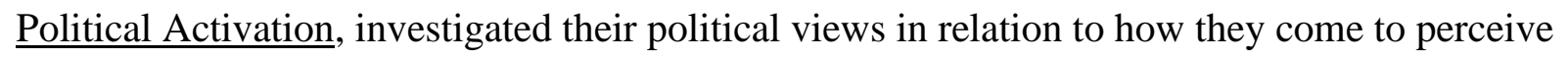
matters related to politics. Racism, as a political matter for the YABMs, involves the evaluation of the extent to which matters of race effects the extent to which exclusionary practices and policies limit his decision to help others in his respective community related to race. 
For Acey, the exclusionary practices of race manifested through his experience with the institution of education and socioeconomic status. More precisely, through the practices of the folks who educated him not just through academics and an emphasis on its importance, but also the extent that he must work harder at it than 'others'. Acey also expressed a distinction in noticing a difference in the perceptions of his attending a private and public school. Each experience illustrating a form of conflict and challenge for Acey. Immediately following Acey's data interpretation, findings from Jason's reflections and responses were conducted.

Jason's reflections and responses had a themes of resistance and tensions with his perceptions of power against his community with matters related to race. The power associations expressed by Jason specifically bring attention to the elements of power that are most detrimental through exclusionary practices, setting the agenda for the amount of challenge forged against folks realizing opportunity associated to his 'race'. However, he also points out another challenge to how he may even be able to interact with 'others' to resolve the matter when they have issue with Black folks having control of the weltanschauung agenda or even discussing them as a matter of race. As he stated, "white people are scared" (Jason 1, interview, lines 79-80). And then there is Nelson.

Nelson's data related to matters of race reflected back upon his experience with the Trayvon Martin killing. His reflective perceptions revealed that his ideology of racism consists of the belief that agents representing the institutions of law have the preconceived notion that he, as a YABM, is a criminal (Crawford, Brandt, Inbar, Chambers, and Motyl 2016; De Cremer, Wubben, and Brebels 2008; Hirschfeld 1938/2016). And a second theme that is revealed about his ideology of racism consists of principles affected by the Walker (2019) version of DuBois' (1897) double consciousness. Walker's (2019) version consists of elements of power that affect 
IOR processes. And then, the transition culminates in the form of a conversation among various authors given their specific writings. The goal for such a form of discussion is to reveal ways by which one may come to understand how these YABM are perceiving and interacting with specific exclusionary prejudices and practices related to race. And moreover, explanations for why he is perceiving and interacting as he reveals through his reflective responses.

Miles and Brown (2003) would suggest that in attempting to come understand how an individual comes to understand terms associated with racism, one should do so from an understanding that includes his perceptions as ideological in nature (Crawford, Brandt, Inbar, Chambers, and Motyl 2016; Miles and Brown 2003). Seidman (2013) instructs that interpretative approaches to analyzing research data should be careful to do so in a manner that is based from participant reflection absent of an interpreter's biases and perceptions. The methodological approach for interpreting the YABM in the study, therefore, was interpretative phenomenological analysis (Denzin 1992; Smith and Osborn 2007; Smith, Flowers, and Larkin 2012).

The study design and interpretive approach engaged an interpretative case study (ICS) structure (Seidman 2013). The ICS enabled an examination of both psychological and sociological artefacts and phenomena given the reflections of the participants. An ICS also allows for the analysis of these artefacts in relation to individual identities, experiences, and perceptions. To engage the ICS structure, the study design for this dissertation adopted symbolic interactionism (SI) as its tool (Denzin 1992; Katovich 1994; Stryker 2003).

Denzin (1992:25) explains that "Symbolic interaction (the merger of self and social interaction) is the chief means 'by which human beings are able to form social or joint acts'." Influenced by Denzin (1992) narrowed his professional foci to the relationships between individual actions as a member of a group. In doing so he advises that a characteristic of SI an 
individual "gives up the role of spectator and voluntarily commits his [her] freedom to the cause" (Denzin 1992:162). It is the gaining insight into this process, the "merger between self and social interaction" from the perspectives of the participants that is a focus of this study.

\section{FINDINGS}

Acey

A response from a study participant, Acey, a 22-year-old college junior at an historically Black university (HBCU) in south central America, represents a basis from which to engage the 'race' related findings. When prompted to reflect upon his earliest experiences of school, he did so through stating,

So, when I first started off to go at school I went to of course when I was really young like toddler age, I did my day care, but I did start of in a private school. It was (XX) academy in (Peachdale, Georgia) and that's where I did my pre-K preschool. I enjoyed it a lot, that was the predominantly African American private school. They did push us a lot and they really made sure that whatever grade we were in, we were definitely well advanced, and we should be, so it wasn't a problem once we continued to get older and branched out. (Acey 2, interview, lines 17-24)

Clearly, Acey did not use the term racism nor race in his reflection. However, his reflection is rich given what has been presented thus far about racism as an ideology given Acey as a YABM in the contemporary weltanschauung. First, the experience became a part of Acey's sense-making, and therefore meaning making and perceptions of the world from "toddler age." Next, the origin of this experience came from folks that were influential at the place from which he understood knowledge to come from, thus most probably significant to those processes (Awokoya 2012; Duncan 2005; Jackson III 2012). Then, the subject matter of the experience 
indicates that the folks of influence are conveying that Acey needs to be "well advanced."

Acey's response in context is ideologically indicative that he needs to be advanced in educational attainments so that as he progresses through life, he was prepared for something; an alert of sorts for his sense-making processes in the weltanschauung. His response then indicates that in order for him to be successful, or "branch out," as he lives his life, he must achieve this being well-advanced in educational attainments. This indication is accentuated through the influential folks "(pushing he and his classmates) a lot." Overall, however, Acey enjoyed the experience of attending an African American private school as the environment within which

this experience occurred. Again, in context, Acey makes a distinction between this school and public schools that he attended in intermediate and high schools. An indication is that there is something potentially significant that he has come to understand as being different when attending a public or private African American school.

\section{Jason}

A second participant, Jason, a 21-year-old junior also attending an HBCU also in the South-Central region, was prompted to reflect upon his experiences and respond with what drives him to be politically active because of his race. Jason responded with the following reflection:

Yes. I feel like, they invite black people to the table, right, and I feel like if you're just sitting at the table that's not enough. But if you really want to make a change and make the difference you have got to be at the head of the table. You have to be in charge of the table. And that's what I want people, well black people mainly to really see. They want us at the table to eat off of us, but they don't want us cooking the meal. (Jason 1, interview, lines 169-174) 
In this case of course, Jason's response includes the qualifier of directly including his meanings for race and ethnicity as premises to his reflective experience. The perspective presents another version of rich content to interpret toward gaining knowledge about YABMs' perceptions and IOR. Firstly, Jason is speaking from a position of resistance and advocacy. Scott (1992) argues for the resistance that oppressed folks have in response to social contexts that challenge his striving for satisfying his best interests as tangible consequences. Resistance to disenfranchisement being indicative of a YABMs' level of internal turmoil. His reference to some "they," moreover, indicates that there is a group of folks for whom the basis of his resistance exists; a reinforcement for an 'othering' dynamic as he processes the activity.

Secondly, Jason's response in context overall is political in nature given his reference to a proverbial "table" at which some agenda is being set, but folks like he have no say in what that agenda consists. Lukes (2005) explains that such occurrences are indicative of dimensional power of domination over the decision-making of oppressed folks specifically. A third indicator of the content of his reflection and response indicative of his IOR, at a level by which he resists and desires to react as advocate to what he has made meaning of as an exclusionary practice in the weltanschauung. Moreover, Jason makes explicit that he is advocating for folks of his Black community. And he ends this specific response by adding that in addition to the "they" are setting the social agenda of the weltanschauung; they do not want the Black community realizing a favorable agenda. In-fact, within the context of his reflections and responses he advises that "I think, I really want to say that -- I don't mean to sound any type of racist but I think white people are scared" (Jason 1, interview, lines 79-80).

\section{Nelson}

And a third participant, Nelson, is an 18-year-old senior attending a large public high 
school in the Midwest. The study included a question that prompted the participant to reflect and respond to a scenario. The scenario was placing themselves in the situation that Trayvon Martin found himself on the fateful night of February 26, 2012. The participants were asked to place themselves in Trayvon's position and advise what they may have said to keep from being mortally wounded. Nelson reflected and responded through stating that "I would just remind him that not all black people are bad. Just lighten up a little bit" (Nelson 2, interview, lines 4344). And when asked to reflect further upon what he meant by using the term "bad," he explained that "We're not out here to put ourselves in situations like being involved in drugs or crime" (Nelson 2, interview, lines 47-48).

A first indicator of Nelson's ideological perspective is one that consists of a negative perception and preconceived notions of himself as a criminal presumably in the eyes of this person because he is a YABM (Crawford, Brandt, Inbar, Chambers, and Motyl 2016; De Cremer, Wubben, and Brebels 2008). Indicative of the double consciousness feelings presented earlier in the DuBoisian sense at least. Secondly, Walker (2019) advises that DuBois (1897) was arguing that double consciousness reveals that Black folks hold a "“peculiar sensation” of 'always looking at one's self through the eyes of others', and 'measuring one's soul by the tape of a world that looks on in amused contempt and pity"' (Walker 2019:117-118). Nelson's use of the term "remind" reveals a position of confusion or conflict in that he believes that the agent of the law knows that he is not a "bad" person just because he is Black.

Each of the participant's reveals indicators of their respective ideologies, characteristics of their respective perceptions of exclusionary practices in the weltanschauung, and characteristics of the processes of the YABMs' IOR in reaction to certain exclusionary practices. Collectively, they reveal the IOR that also begins to reveal itself that require explanation for use 
of this phrase to establish the activity of racism in terms of being a complex ideology rather than merely an expression of xenophobia or superiority. An IOR is not synonymous with racism, and racism is not synonymous with being racist (Miles and Brown 2003). Being racist is making judgment of another based from merely an observed phenotypic difference and or expression that one’s 'nation' is superior over another (Hirschfeld 1938/2016; Miles and Brown 2003).

\section{DISCUSSION}

An IOR is the politically based process of thinking and principles for interacting with the world as one has come to understand it at any given point-in-time. That process of thinking and principle includes how one comes to perceive, make meaning of, integrates a level of satisfaction of basic psychological needs, and interacts with the world when matters of race are associated with exclusionary practices (Miles and Brown 2003). The purpose of this article is to seek additional knowledge toward coming to understand YABMs' perceptions and political activations when prompted by the phenomenon of racism. The respective IORs reveal rich content from which to formulate understandings of their perceptions as political exercises.

The content opens a door that begins to reveal particular perceptions from which to interpret each YABM participant's political components for his IOR and perceptions of racism related social phenomena. As explained earlier, those components include their perceptions for how the characteristics of helping others in their community when exclusionary practices of racism are determined to be part of the weltanschauung. However, Kendi (2019) presents a conception and understanding for what racism is that is excellent as another perspective from which to continue the discussion and argument for racism being understood as an ideology.

Given the presented representation that racism is an ideology, Kendi (2019) would argue for a different understanding for the term from the Gramscian based nature earlier. Kendi 
(2019:17-18) explains that "racism is a marriage of racist policies and racist ideas that produces and normalizes racial inequities." Miles and Brown (2003) would respond by first pointing out a distinction between marrying the terms 'racism', 'racist' and the phrase 'racist policies'. Or as Hirschfeld (1938/2016:129) advises, "race is not so much a cognition as an avowal, an avowal of character-values." Then including that conflation with a process that involves normalizing racial inequities. Overall, however, Miles and Brown (2003) would also add that Kendi's (2019) conclusions are not necessarily exclusive of their position of 'racism' as an ideology. Let us explore how by considering how Kendi breaks down each term, and then his conveyance for what is intended by the process as a production and normalizing of racial inequities.

Kendi (2019:18) elaborates that racial inequity "is when two or more racial groups are not standing on equal footing." Miles and Brown (2003) would advise agree with this definition. However, they would explain that the racial inequities, as may be experienced by the participants, would be associated as phenomena of racism and part of the weltanschauung. The YABM would then include in their respective IOR given said exclusionary practice(s). Kendi (2019:18) also explain that "a racist policy is any measure that produces or sustains racial inequity between racial groups." Miles and Brown (2003) would also agree with Kendi (2019) here under a belief that racism is an institution. And that the institution of racism produces social creations, like policies, which are racist or exclusionary in nature and when practiced.

Miles and Brown (2003) would use the same explanation as above and elaborate by including that they see being 'racist' may be a form of resistance against exclusionary policies as may be exhibited by a YABM. However, there is one very important qualifier that must be included in that process of resistance if the YABM would be acting as a 'racist'. To be resisting, or merely acting as a racist, part of the resistance process would include a decision to react based 
from an associated difference to some physical or cultural characteristic; perceived difference in nationality (e.g. a 'white' man perceiving a member of a native American tribe); and an assignment of the perceiving individual making a judgment of superiority over an observed differing individual or group (Hirschfeld 1938/2016). Carrying these qualifiers forward, however, Miles and Brown (2003) only imply that phenotypic and superiority/inferiority revealed through social practices evidence the potential for Acey's exhibiting racist tendency.

Miles and Brown (2003) and Lukes (2005) would add an element of power by using the term tangible in association to the phrase racist policy and Walker's (2019) version of double consciousness as a form of domination over the YABMs. And the production and normalizing functions of racial inequities are consistent with racism as an ideology because he would associate with exclusionary phenomena of racism. As illustrated earlier, each presented YABM participant illustrates the complementary distinctions made among Kendi (2019) and Miles and Brown (2003) while teasing how power and the double consciousness of Lukes (2005) and Walker (2019) nuance the process of perceiving and or resisting racism related phenomena. We will engage the finding offered by Acey to continue.

\section{Acey}

As may be recalled, the finding from Acey did not contain any terms related to racism. This does not mean that his IOR is not engaged, however. Considering Acey's response in terms of identity development, Pezzulo (2011) and Pine and colleagues (2013) would bring to our attention that "individual social and political identity development is indicative of how perceptions are formed and acted upon" (Crayton 2019:6). Each author would then add that conceptions of racism were impressed upon him as a toddler. Walker (2019) would call attention to the fact that to some degree double consciousness may be affecting Acey as early as when he 
was a toddler. And Lukes (2005) would be drawn in to make one aware that evidence of Walker's (2019) double consciousness bares the potential to some level of domination over Acey's decision making due to a presence of power.

Pezzulo (2011) and Pine and colleagues (2013) would explain that this impression would affect the development of Acey's actual identity. Belgrave and Allison (2014) would further advise Acey's “perceptions are reflective of an individual's knowledge and understanding of that which is perceived" (Crayton 2019:6). Hibbing, Smith, and Alford (2014) may then jump in and argue that there are also physiological influences on individual political tendencies at a subconscious level as well. Awokawa (2012) would substantiate Hibbing, Smith and Alford (2014) by adding that school personnel are greatly influential to community specific students and their respective perceptions of his identities.

Bringing attention specifically to Acey's reflection where he offers that school personnel stressed the importance of high educational attainment, Yates and Youniss (2002) would jump into the conversation. Walker (2019), and by default again Lukes (2005), would cosign with the fact that double consciousness has joined Acey's IOR again during this reflection within his IOR criteria. Yates and Youniss (1998:495) would jump back into the conversation by arguing that Acey's reflection has additional significance in that "youth reflect on values, ideologies, and traditions of their communities and the possible roles they will undertake in adulthood." Miller (1980) may then point to Acey's reflection and suggest that his political perceptions associated to racism related context to socioeconomic and class as he included a distinction between attending the private and public schools. They would clarify that their IOR includes these aspects as significant as criteria to function in the weltanschauung. Crawford, Brandt, Inbar, Chambers, and Motyl (2016) elaborated by suggesting that social and economic beliefs play into Acey's 
IOR processes. And then the discussion moves to Jason's reflection.

\section{Jason}

The discussion continued about the finding represented by Jason's reflective responses. As may be recalled, Jason was prompted to reflect upon his experiences and respond with what drives him to be politically active related to what he considers to be his race. His began that response by stating, "Yes. I feel like, they invite black people to the table, right, and I feel like if you're just sitting at the table that's not enough" (Jason 1, interview, lines 169-174). Lukes (2005) jump starts the discussion by arguing that Jason is conveying a significant exhibition of power by pointing out that Jason is resistant to an established agenda, established by a community other than his own as a YABM - the "they." And Walker (2019) would be sure to add that as far as insight into Jason's perceptions of the situation, he desires to work for some way to change such practices as a characteristic of his IOR.

Ryan and Deci (2017) would then bring attention to the portion of Jason's responses that indicating that a member of his community must be in charge of the agenda referencing racism related exclusionary practices. They would then say that his response reflects some insight into Jason's perceptions of racism related practices of the weltanschauung and an extent to which he desires to act based from a process of internalization as a level of motivation to act. Ryan and Deci (2017) would then say that Jason finds this need to act very important even though exclusionary practices related to his ideology of racism indicates strong presence of introjection, or power, to act outside his interests and basic psychological needs. Scott (1992) interrupted and said that Jason is exhibiting resistance based on the feelings of being 'othered' by "they."

Deci and Flaste (1996) eagerly jumped back in and clarify that the introjection referred to, by Ryan and Deci (2017), more specifically indicates that the power of introjection "is 
essentially one of exerting external controls to program people's behavior [and] perspective that sees socialization as something that gets done to people" (Deci and Flaste 1996:92). Kirshner (2015) would add that Jason is indicating that his ideology of racism represents his perception that it reminds them of a study that they conducted. Kirshner (2015) would point precisely to Jason's stating that "they want us at the table to eat off of us, but they don't want us cooking the meal" (Jason 1, interview, lines 169-174). And the point that "youth [have] articulated, (that when interests were) discounted in the decision-making process, (they) challenged prevailing assumptions about school quality" (Kirshner 2015:101).

De Cremer, Wubben, and Brebels (2008) then brings to the attention of the discussants that their studies of YABM reveal tendencies to pay attention to the fact that their reactions to authority depends upon the emotion evoked when they are engaged. Miles and Brown (2003) agreed with De Cremer, Wubben, and Brebels (2008) referring to Jason's explaining that "white people are scared" (Jason 1, interview, lines 79-80). DiAngelo (2018:2) interjected immediately that Jason's assessment did not sound unfounded because "in fact, when we try to talk openly and honestly about race, white fragility quickly emerges as we are so often (react) with silence, defensiveness, argumentation, certitude, and other forms of pushback."

The statement caused the majority of the discussants to digest at this point. After a minute or two, Ryan and Deci (2017) chimed in and qualified by an implication that by pointing out that he felt that his IOR was affected because he associated the perception of white folks being scared of having Black folks in-charge of the weltanschauung's agenda with being seen as racist. Miles and Brown (2003) thoughtfully add that Jason's IOR has a characteristic of trying not to be seen as someone who basis his actions on someone's race. Walker (2019) immediately elaborated stating that, "yes," and Jason is again exhibiting characteristics of her version of 
double consciousness indicating that the weltanschauung consists of exclusionary practices that must be navigated by him.

\section{Nelson}

Lee, Steinberg, Piquero, and Knight (2011) restart the discussion when they brought the discussants' attention to Nelson's response. They said that thinking about feelings of folks in authority clearly are perceived to have some preconceived negative conceptions about him as a YABM pertaining to racism. De Cremer, Wubben, and Brebels (2008) then say that Nelson's response echoes Jason when he assessed that white folks were scared as criteria within his IOR. Miles and Brown (2003) then mused audibly that something significant about predicting their respective perceptions of interactions with a racism associated weltanschauung for YABM.

The discussants seemed to pay even closer attention to the discussion when DuBois (1897) broke his silence. He first asked, where did this term racism come from? Hirschfeld (1938/2016) explained that there is no definite idea when the term came to be. However, its use seemed to surface circa in 1933 to identify a distinction being made by the Fascists of his country, Germany, and Jewish folks. It's basis was falsely based on supposed biological and nationalistic differences among the them. I see DuBois (1897) replied. The term then attached to other folks who appeared to be different because of skin color or perceived cultural difference. Then he brought the discussants' attention to Nelson's stating that he "would just remind him that not all black people are bad" (Nelson 2, interview, lines 43-44). He went on to remind the discussants that "the history of the American Negro is the history of this strife, - this longing to attain self-conscious manhood, to merge his double self into a better and truer self” (DuBois, 1897:1).

Crawford, Brandt, Inbar, Chambers, and Motyl (2016) agree and emphasize that certain 
social prejudices predict preconceived notions against ethnic minorities. They went on to say that Nelson seemed to be conveying that the perceptions of his IOR revealed that agents of the law believe that YABM are immoral or bad like being "out here to put ourselves in situations like being involved in drugs or crime" (Nelson 2, interview, lines 47-48). And DuBois (1897), affected by Walker (2019) and Lukes (2005) associations of his conceptions of double consciousness and power, made clear that YABMs, like Jason, Nelson, and Acey must have heavy burdens given the power exuded by the weltanschauung and the constant feelings of 'peculiar sensations'. Burdens, because of how they look and sociohistorically considered inferior as YABM who are coerced to alter their IOR toward favoring interest realization as participants within the American weltanschauung.

\section{CONCLUSION}

The purpose of this article is to seek additional knowledge of the perceptions and political activations of YABMs' when race related exclusionary practices are encountered. Toward establishing this purpose, there is first a determination established for what racism is among discussants (Hirschfeld 1938/2016; Kendi 2019; Miles and Brown 2003). Kendi (2019:17) explains that "to be an antiracist is to set lucid definitions of racism/antiracism... To be a racist is to be constantly redefine racist in a way that exonerates one's changing policies, ideas, and personhood." In mid-April of 2019, a survey was presented to my connections on LinkedIn. The connections were asked to answer the following question, "In no more than two sentences, what is racism?" A sample of the responses ranged from "tribalism" to "Applying preconceived ideas about a race and filtering an interaction/situation with a person or group through that perception without questioning or reflecting on those indirect 'mental influences'." Given the exemplification for a need to establish a commonly understood basis for a premise of 'racism', the article consisted of the following context. 
Miles and Brown (2003) provide the basis for the initial section, What is Racism? The strategy and content for this section actually argued for what racism is not toward establishing a foundation from which to build upon. First, racism is not a static conception or phenomenon that represents manifestations of hate and beliefs that one 'race' is superior to another. The next section, Racism is an ideology, provides criteria by which the processes for making-meaning, decision-making, and principles from which to react when confronted with perceived exclusionary practices or policies related to race. Those criteria being related to the extent to which the YABMs' respective basic psychological needs and self-determination are satisfied (Ryan and Deci 2017; Omi and Winant 2015).

The racism weltanschauung as coherent and incoherent phenomena begins by providing an explanation for the relevance of distinguishing between prejudicial (i.e. person-to-person) and institutional (i.e. practices and policies) race related exclusionary practices encountered in American society. And it transitions through the presentation that resistance to the hegemony of the weltanschauung becomes a part of the meaning and decision-making process for the YABM. More precisely, it is discovered that both coherent and incoherent versions of exclusionary

practices and prejudices are related to "class interests and strategies, different strategies (learned) of resistance, and different material and cultural contexts" (Miles and Brown 2003:171) of the YABM. Carrying these discoveries forward, the Findings section reveals data from which insights into the meaning-making, decision-making, and perceptions of a group of YABMs are revealed.

\section{The Principles of Acey's Ideology of Racism}

And the conversation among the authors produced content from which an assessment of the YABMs respective ideologies of racism principles was developed. First, a characteristic that 
is indicative of Acey's IOR, is that he did not use the term racism, or any other term related to race in his responses. As Pezzulo (2011) and Pine and colleagues (2013) reveal, a first principle revealed about Acey's IOR is that his identity plays an important role. Collins and Bilge (2016:7) would add that components of intersectionality, as applicable, such as "race, class, gender, sexuality, dis/ability, ethnicity, nation, religion, and age" would specifically play into his IOR just as much. To clarify, to the extent that Acey has associated exclusionary prejudices and practices related to those components of identity with which he identifies plays into his IOR processes.

Awokawa (2012) and Hibbing, Smith and Alford (2014) would suggest that a second principle for Acey's IOR is based from experiences with his representatives in his respective community's educational institutions. And that Yates and Youniss (1998) would add the extent to which such considerations illustrate his ability to be successful later in life, the more influential in his IOR processes as a principle. Crawford, Brandt, Inbar, Chambers, and Motyl (2016) would clarify further that the term 'success' would be the extent to which Acey believed that he attained a certain socioeconomic class status in-life.

\section{The Principles of Jason's Ideology of Racism}

A theme that clearly revealed a first principle of Jason's IOR are exclusionary practices or policies that threaten his community as a YABM (Ryan and Deci 2017). Folks like Walker (2019) and Lukes (2005) would add the level with which this principle would affect his IOR processes is the extent to which he feels that he can affect the agenda setting power that the experienced exclusionary practice exhibits (Kirshner 2015). Ryan and Deci (2017) would add that a second principle for Jason's IOR, from a political perspective, would be the fact that to the extent that he is able to address the first principle, he satisfies a basic psychological need of 
helping others in his community as a YABM to resist exclusionary practices or policies.

Deci and Flaste (1996) would add that the level of motivation through which Jason's IOR processes would be engaged depend upon the extent to which he believes the exclusionary practice or policy related to racism is affecting his community. And a third principle as would be pointed out by De Cremer, Wubben, and Brebels (2008) and DiAngelo (2018) would be Jason's belief that white folks are scared of Black folks being in-charge of the American weltanschauung. Jason advised that the extent to which this principle influences his IOR processes depends on the extent to which he may be seen as a "racist."

\section{The Principles of Nelson's Ideology of Racism}

Lee, Steinberg, Piquero, and Knight (2011) would advise that a principle of Nelson's IOR is that agents of the law cannot be trusted because he believes that they have preconceived notions of his being criminal because he is a YABM. De Cremer, Wubben, and Brebels (2008) may add that the extent to which this belief influences Nelson's IOR processes is the extent to which the agent with whom he is encountering is afraid of him. As with Jason's principles, DiAngelo (2018) would probably substantiate such a claim. Crawford, Brandt, Inbar, Chambers, and Motyl (2016) may then suggest a second principle that Nelson's IOR exhibits. That principle, given the context of Nelson's responses, indicate that opportunities to remedy the beliefs of his first principle exists as a basic psychological need for him (DuBois 1897; Ryan and Deci 2017). As expressed earlier in the article by DuBois (1897:1), "the history of the American Negro is the history of this strife, — this longing to attain self-conscious manhood, to merge his double self into a better and truer self." In-fact, the application would then apply to every YABMs' IOR within this American weltanschauung. 


\section{REFERENCES}

Artiles, A. J. 2011. “Toward an Interdisciplinary Understanding of Educational Equity and Difference: The Case of the Racialization of Ability." Educational Researcher, 40(9), 431- 445 .

Awokoya, J. 2012. "Identity Constructions and Negotiations Among 1.5- and SecondGeneration Nigerians: The Impact of Family, School, and Peer Contexts." Harvard Educational Review, 82(2), 255-281. doi:10.17763/haer.82.2.9v77p329367116vj

Ball, T., and Dagger, R. 2002. Political Ideologies and the Democratic Ideal (Fourth ed.). New York, San Francisco, Boston: Longman - Addison Wesley Educational Publishers.

Ball, T., Dagger, R., and O'Neill, D. 2014. Political Ideologies and the Democratic Ideal (Ninth ed.). Boston, Columbus, Indianapolis, New York, San Francisco, Upper Saddle River, Amsterdam, Cape Town, Dubai, London, Madrid, Milan, Munich, Paris, Montréal, Toronto, Delhi, Mexico City, São Paulo, Sydney, Hong Kong, Seoul, Singapore, Taipei, Tokyo: Person.

Belgrave, F., and Allison, K. 2014. African American Psychology: From Africa to America (Third ed.). Los Angeles and London: Sage.

Brave, R., and Sylva, K. 2007. "Exhibiting Eugenics: Response and Resistance to a Hidden History." The Public Historian, 29(3), 33-51. doi:10.1525/tph.2007.29.3.33

Carmichael, S. 2018. "If a Man Wants to Lynch Me.” Stokely Carmichael. Retrieved from https://www.goodreads.com/quotes/7802915-if-a-white-man-wants-to-lynch-me-that-s$\underline{\text { his }}$

Collins, P., and Bilge, S. 2016. Intersectionality. Cambridge, UK, Malden, MA: Polity Press. Crawford, J., Brandt, M., Inbar, Y., Chambers, J., and Motyl, M. 2016. "Social and Economic 
Ideologies Differentially Predict Prejudice Across the Political Spectrum, but Social Issues are Most Divisive. Multi-Dimensional Ideological Conflict Tilburg. the Netherlands.

Crayton, T. (2019). Toward Gaining Knowledge of Young Adult Black Males’ Perceptions of Political Activation. (Ph.D. Dissertation), Indiana University Purdue University Indianapolis, Ann Arbor, MI.

Deci, E., and Flaste, R. 1996. Why We Do What We Do: Understanding Self-Motivation. New York: Penguin Books.

De Cremer, D., Wubben, M., and Brebels, L. 2008. "When Unfair Treatment Leads to Anger: The Effects of Other People's Emotions and Ambiguous Unfair Procedures." Journal of Applied Social Psychology, 38(10), 2518-2549. doi:10.1111/j.1559-1816.2008.00402.x

DiAngelo, R. 2018. White Fragility: Why It's So Hard for White People to Talk About Racism. Boston: Beacon Press.

DuBois, W. 1897. "Strivings of the Negro People.” The Atlantic. Retrieved from August 1897. https:/www.theatlantic.com/magazine/archive/1897/08/strivings-of-the-negropeople/305446/

Duckitt, J., and Sibley, C. G. 2010. "Personality, Ideology, Prejudice, and Politics: A DualProcess Motivational Model Duckitt and Sibley Dual-Process Motivational Model.” Journal of Personality, 78(6), 1861-1894. doi:10.1111/j.1467-6494.2010.00672.x

Duncan, G. A., and McCoy, H. 2007. "Black Adolescent Racial Identity and Respectability." Negro Educational Review, 58(1/2) 35-48.

Eberhardt, J. 2019. Biased: Uncovering the Hidden Prejudice That Shapes What We See, Think, and Do (1st ed.). New York: Viking.

Gramsci, A. 1971. Selections from the Prison Notebooks. (Ed.) London: Lawrence and Wishart. 
Heitzeg, N. A. 2015. “'Whiteness,' Criminality, and the Double Standards of Deviance/Social Control.” Contemporary Justice Review, 18(2). 197-214. doi:10.1080/10282580.2015.1025630

Heywood, A. 2003. Political Ideologies: An Introduction (Third ed.): Palgrave MacMillan.

Hibbing, J., Smith, K., and Alford, J. 2014. “Differences in Negativity Bias Underlie Variations in Political Ideology.” Faculty Publications: Political Science (37). 297-350. doi:10.1017/S0140525X13001192

Hirschfeld, M. 1938/2016. Racism (Reprint ed.). (Ed.) London and Delhi: Victor Gollancz LTD and Facsimile Publishers.

Hodgson, G. 2006. “What are institutions?” Journal of Economic Issues. 40(1). 1-25.

Kirshner, B. 2015. Youth Activism in an Era of Education Inequality. New York and London: New York University Press.

Lee, J. M., Steinberg, L., Piquero, A. R., and Knight, G.P. 2011. "Identity-Linked Perceptions of the Police Among African American Juvenile Offenders: A Developmental Perspective.” Journal of Youth and Adolescence. 40(1), 23-37. doi:10.1007/s10964-010-9553-2

Lukes, S. 2005. Power: A Radical View (Second ed.). Great Britain: Palgrave Macmillan.

Miles, R., and Brown, M. 2003. Racism (Second ed.). London and New York: Routledge.

Miller, E. F. 1980. “What Does 'Political' Mean?” The Review of Politics. 42(1), 56-72.

Omi, M., and Winant, H. 2015. Racial Formation in the United States (Third ed.). New York, NY: Routledge.

Ryan, R., and Deci, E. 2017. Self-Determination Theory: Basic Psychological Needs in Motivation, Development, and Wellness. New York and London: The Guilford Press. Scott, J. 1992. Domination and the Arts of Resistance: Hidden Transcripts. New Haven and London: Yale University Press. 
Searle, J. 1995. The Construction of Social Reality. New York: The Free Press.

Smith, J., Flowers, P., and Larkin, M. 2012. Interpretative Phenomenological Analysis: Theory, Method and Research. Los Angeles, London, New Delhi, Singapore, and Washington D.C.: Sage.

Walker, L. E. 2019. “Double Consciousness in Today's Black America.” Stance, 12, 116-123.

Youniss, J., Bales, S., Christmas-Best, V., Diversi, M., McLaughlin, M., and Silbereisen, R. 2002. "Youth Civic Engagement in the Twenty-First Century." Journal of Research on Adolescence. Wiley-Blackwell. 12(1). 121. 